\title{
Low Molecular Weight Hyaluronic Acid (500-730 Kda) Injections in Tendinopathies-A Narrative Review
}

\author{
Antonio Frizziero ${ }^{1, *}$, Filippo Vittadini ${ }^{2}$, Davide Bigliardi ${ }^{1}$ and Cosimo Costantino ${ }^{1}$ (D) \\ 1 Department of Medicine and Surgery, University of Parma, 43126 Parma, Italy; \\ davide.bigliardi@unipr.it (D.B.); cosimo.costantino@unipr.it (C.C.) \\ 2 Department of Physical and Rehabilitation Medicine, Casa di Cura Policlinico S. Marco, 30100 Venice, Italy; \\ filippo.vittadini@gmail.com \\ * Correspondence: antonio.frizziero@unipr.it
}

Citation: Frizziero, A.; Vittadini, F.; Bigliardi, D.; Costantino, C. Low Molecular Weight Hyaluronic Acid (500-730 Kda) Injections in Tendinopathies-A Narrative Review. J. Funct. Morphol. Kinesiol. 2022, 7, 3. https://doi.org/10.3390/jfmk7010003

Academic Editors: Giuseppe

Musumeci and Silvia Ravalli

Received: 2 December 2021

Accepted: 27 December 2021

Published: 29 December 2021

Publisher's Note: MDPI stays neutral with regard to jurisdictional claims in published maps and institutional affiliations.

Copyright: (C) 2021 by the authors. Licensee MDPI, Basel, Switzerland. This article is an open access article distributed under the terms and conditions of the Creative Commons Attribution (CC BY) license (https:// creativecommons.org/licenses/by/ $4.0 /)$.

\begin{abstract}
Tendinopathies are common causes of pain and disability in general population and athletes Conservative treatment is largely preferred, and eccentric exercise or other modalities of therapeutic exercises are recommended. However, this approach requests several weeks of consecutive treatment and could be discouraging. In the last years, injections of different formulations were evaluated to accelerate functional recovery in combination with usual therapy. Hyaluronic acid (HA) preparations were proposed, in particular LMW-HA (500-730 kDa) for its unique molecular characteristics in favored extracellular matrix homeostasis and tenocyte viability. The purpose of our review is to evaluate the state-of-the-art about the role of 500-730 kDa in tendinopathies considering both preclinical and clinical findings and encourage further research on this emerging topic.
\end{abstract}

Keywords: tendinopathy; hyaluronic acid; injection

\section{Introduction}

Tendinopathy is multifactorial pathology, that could lead to chronic pain and functional impairment [1]. The rotator cuff [2], the long head of the biceps [3], the wrist extensors and flexors [4], the adductors [5], the patellar tendon, the Achilles tendon [6] and the posterior tibial tendon [7] are the most affected tendons.

Tendinopathies are largely triggered by overload [8], but a great number (about one third) of patients do not practice regular physical activity [9].

Tendinopathies can occur in acute and chronic state and can be supported by different factors both intrinsic (age [10], body structure [11], nutrition [12], metabolic diseases [13,14], genetics [15]) and extrinsic (excessive and improper fatigue [8,16], detraining [17], and external damage [18-20]) factors. All these factors seem to be related to the appearance of overload tendinopathy although a cause-effect relationship has not yet been demonstrated.

Tendinopathies are characterized by disorganization of collagen fibers with dysregulation in extracellular matrix homeostasis, alteration in proteoglycan content, enhanced tenocyte apoptosis, and increase in the microvasculature and sensory nerve innervations $[19,21]$. Additionally, paratenon shows mucoid degeneration, fibrosis, and vascular proliferation with mild inflammatory infiltrate [22].

There are currently no treatments of choice for tendinopathies as no strong evidence has yet been found that one treatment is better than another $[1,23,24]$. Until a few years ago, eccentric exercise [25-27] and extracorporeal shock wave therapy (ESWT) [28] showed significant effects on both pain and functional recovery.

Recently, thanks also to the ultrasound high-definition evaluation and guide [29], injection therapy has also carved out an important role in the treatment of tendinopathies through different proposals with different levels of success, as hyaluronic acid [30], PRP [31], high volume injections [32], prolotherapy [33,34], autologous conditioned serum [35], sclerotherapy [34], percutaneous electrolysis [36], etc. 
Hyaluronic acid (HA) is a polymer of disaccharides, which are composed of Dglucuronic acid and $N$-acetyl-D-glucosamine, linked via alternating $\beta-(1 \rightarrow 4)$ and $\beta-(1 \rightarrow 3)$ glycosidic bonds [37].

In particular, HA allows a smooth tendon gliding and provides nutrition to tendon itself, and it is an important component of tendon structure, being largely present in extracellular space.

HA can be classified by origin (rooster combs or bacterial fermentation), molecular organization (linear, cross-linked, or hybrid), and molecular weight [38]:

- Low molecular weight: <1000 KDa;

- Medium molecular weight: $1000 \mathrm{KDa}<\mathrm{MW}<2000 \mathrm{KDa}$;

- High molecular weight: $>2000$ KDa.

Most of the physiological effects of exogenous hyaluronic acid and its viscosity depend primarily on the molecular weight of the molecule, consequently influencing its possible applications [30].

Low molecular weight hyaluronic acid (500-730 KDa) formulations were the first proposed in clinical practice for knee osteoarthritis since 1990, considering "viscosupplementation" as purpose with high safety profile [39-41]. However, several preclinical and clinical studies increased the knowledge about the numerous possible effects of the interaction with articular tissues as cartilage subchondral bone, synovial membrane, and most recently on tendons.

In recent years, the role of low molecular weight HA (LMW-HA) is emerging among the possible treatments of tendon pathology, secondary to the growing scientific evidence in the preclinical field and to the greater sophistication of ultrasound and techniques to perform therapeutic interventions safely [42].

The purpose of the present study is to perform a descriptive review to highlight the state of the art on the efficacy of hyaluronic acid at low-molecular weight injections in the treatment of tendinopathies.

\section{Materials and Methods}

The present systematic review was conducted on common electronic databases including PubMed (MEDLINE), Pedro, and Cochrane Library. Each database was searched according to its specific syntax rules. Moreover, manual search of published and unpublished studies (conference abstracts, textbooks, 'grey' literature) was also conducted and reference lists of retrieved articles were screened. Search results were limited to studies written in English and published until August 2021. Studies were selected using the following keywords alone or in combination: "hyaluronic acid", "low molecular weight hyaluronic acid 500-730 KDa", "tendinopathy", "tendon" and "injection". The search results and the relative selection process are shown in the following flowchart (Figure 1).

\section{Study Selection}

The selection criteria were: (i) language of publications (English); (ii) study design (preclinical studies, RCT or prospective studies); (iii) sample, including adult patients with a diagnosis of Achilles, patellar or supraspinatus tendinopathy, lateral epicondylitis, or trigger digit; (iv) outcome measures, including pain and functional improvement, patient satisfaction, or return to sport; (v) treatment, consisting in hyaluronic acid injection, alone or associated with other therapies (i.e., exercise). Using the above-mentioned criteria, relevant studies were selected after reading the title and/or abstract, while publications that did not meet the criteria were excluded. Full text from articles selected for inclusion in the review was read, and the bibliographies were hand searched for further relevant publications. As a result, some studies were withdrawn after reading the full text, whereas others were retrieved from the bibliography of the selected articles. 


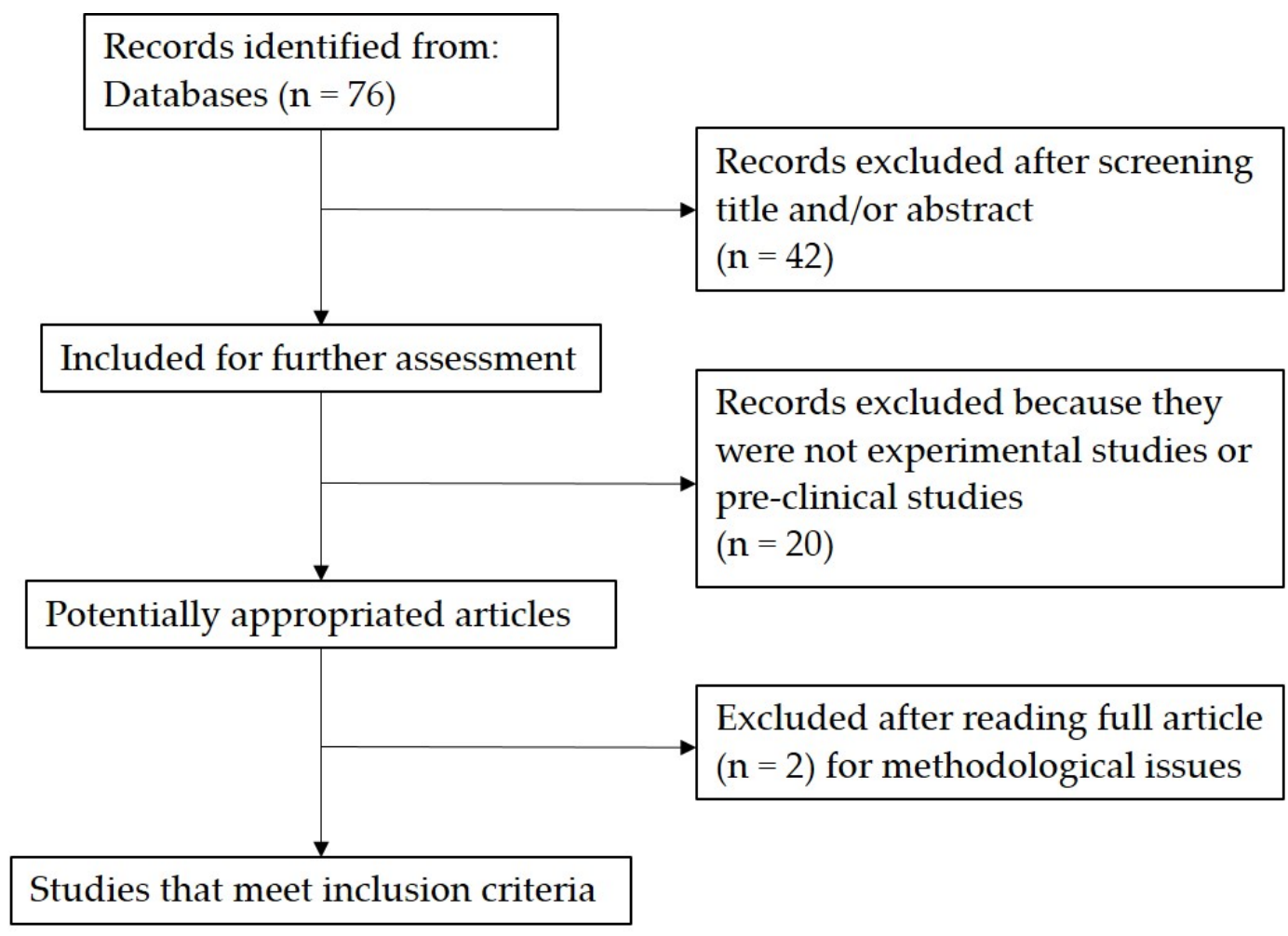

Figure 1. Summary of studies identification and selection.

\section{Results}

The initial search yielded 76 articles, of which 34 were identified as relevant after screening of titles/abstract. Twenty records were excluded because they were not experimental studies or pre-clinical studies. Two papers were excluded after reading full article for methodological issues.

Finally, 12 papers were retrieved from literature search. Among them, 8 clinical studies were selected. Only one compared LMW-HA against placebo; 4 were RTC; and 2 published observational study (Tables 1 and 2).

\subsection{In Vitro Studies}

Osti et al. evaluated the effects of four different hyaluronic acid formulations on viability, metabolic activity, apoptosis, and collagen type I and collagen type III expression on human rotator cuff tendon tears derived cells. The authors found that all hyaluronic acid preparation were efficient in amelioration of cell-metabolic activity, decrease rate of the apoptosis of tendon derived cells and increase Collagen I production in dose dependent manner not related to the molecular weight [43].

Gallorini et al. investigated the antioxidant effects of the same four HA formulations and concluded that all the molecules have protective effects against the oxidative stressrelated cytotoxicity. However, protective effects appear to be particularly efficient in tendon cells treated with LMW-HA (500-730 KDa) [44]. 
Table 1. Four papers were retrieved from literature search. Among them, 2 in vitro studies, 2 pre-clinical studies were selected.

\begin{tabular}{|c|c|c|c|c|}
\hline \multicolumn{5}{|c|}{ In Vitro Studies } \\
\hline Article & Sample Description & Experimental Group & Control Group & Outcome \\
\hline Osti et al., 2015 & Human rotator cuff tears tendon-derived cells & $\begin{array}{c}250 \mu \mathrm{g} / \mathrm{mL} \text { GROUP-MW 500-730 KDa, } \\
500 \mu \mathrm{g} / \mathrm{mL} \text { GROUP-MW 500-730 KDa, } \\
1000 \mu \mathrm{g} / \mathrm{mL} \text { GROUP-MW 500-730 KDa, } \\
250 \mu \mathrm{g} / \mathrm{mL} \text { GROUP-MW } 1000 \mathrm{KDa}, \\
500 \mu \mathrm{g} / \mathrm{mL} \text { GROUP-MW } 1000 \mathrm{KDa}, \\
1000 \mu \mathrm{g} / \mathrm{mL} \text { GROUP-MW } 1000 \mathrm{KDa}, \\
1000 \mu \mathrm{g} / \mathrm{mL} \text { GROUP-MW } 1600 \mathrm{KDa}, \\
1000 \mu \mathrm{g} / \mathrm{mL} \text { GROUP-MW } 2200 \mathrm{KDa},\end{array}$ & Untreated cells & $\begin{array}{l}\text { Tenocyte viability and proliferation, Apoptosis induction, } \\
\text { Immunofluorescence staining }\end{array}$ \\
\hline Gallorini et al., 2019. & Human supraspinatus tendon-derived cells & $\begin{array}{c}\mathrm{H}_{2} \mathrm{O}_{2} \text { GROUP: cultured cells were exposed to } 2 \mathrm{mM} \mathrm{H}_{2} \mathrm{O}_{2} \\
1000 \mathrm{KDa} \text { MW GROUP } \\
2200 \mathrm{KD} \text { MW GROUP } \\
500-730 \mathrm{KDa} \text { MW GROUP } \\
1600 \mathrm{KD} \text { MW GROUP } \\
\mathrm{H}_{2} \mathrm{O}_{2}{ }^{+} \text {HA GROUPS: cells were treated with different } \\
\text { hyaluronic acids in the presence of } 2 \mathrm{mM} \mathrm{H}_{2} \mathrm{O}_{2}\end{array}$ & Untreated cells & $\begin{array}{l}\text { Cytotoxicity-lactate dehydrogenase (LDH) release assay, } \\
\text { immunofluorescence staining of CD4, measurement of } \\
\text { mitochondrial membrane potential (TMRE assay) by flow } \\
\text { cytometry, cell lysis and protein extraction, immunoblotting, } \\
\text { catalase activity }\end{array}$ \\
\hline \multicolumn{5}{|c|}{ Pre-Clinical Studies } \\
\hline Article & Sample Description & Experimental Group & Control Group & Outcome \\
\hline Salamanna et al., 2014 & $\begin{array}{l}24 \text { male Sprague-Dawley rats, aged } 8 \text { weeks, } \\
280 \pm 40 \mathrm{~g} \text { body weight, } \\
\text { Patellar tendon } \\
18 \text { rats run on a treadmill } 1 \mathrm{~h} \text { a day, three } \\
\text { times a week for } 10 \text { weeks. The other six rats } \\
\text { underwent no training }\end{array}$ & 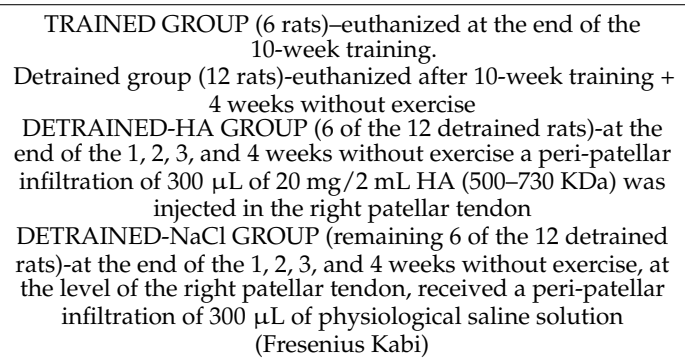 & $\begin{array}{l}\text { UNTRAINED GROUP }(6 \\
\text { rats)-euthanized without training }\end{array}$ & $\begin{array}{l}\text { Tenocyte morphology and morphometric analysis } \\
\text { (transmission electron microscopy), tenocyte viability and } \\
\text { proliferation (Alamar blue dye test), tenocyte synthetic } \\
\text { activity }\end{array}$ \\
\hline Frizziero et al., 2015 & $\begin{array}{l}24 \text { male Sprague-Dawley rats, aged } 8 \text { weeks, } \\
280 \pm 40 \mathrm{~g} \text { body weight, } \\
\text { Patellar tendon } \\
18 \text { rats run on a treadmill } 1 \mathrm{~h} \text { a day, three } \\
\text { times a week for } 10 \text { weeks. The other six rats } \\
\text { underwent no training }\end{array}$ & $\begin{array}{l}\text { TRAINED GROUP ( } 6 \text { rats)-euthanized at the end of the } \\
\text { 10-week training. } \\
\text { Detrained group ( } 12 \text { rats)-euthanized after 10-week training + } \\
4 \text { weeks without exercise } \\
\text { DETRAINED-HA GROUP ( } 6 \text { of the } 12 \text { detrained rats)-at the } \\
\text { end of the } 1,2,3 \text {, and } 4 \text { weeks without exercise a peri-patellar } \\
\text { infiltration of } 300 \mu \mathrm{L} \text { of } 20 \mathrm{mg} / 2 \mathrm{~mL} \mathrm{HA}(500-730 \mathrm{KDa} \text {, Fidia) } \\
\text { was injected in the right patellar tendon } \\
\text { DETRAINED-NaCl GROUP (remaining } 6 \text { of the } 12 \text { detrained } \\
\text { rats)-at the end of the } 1,2,3 \text {, and } 44 \text { weeks without exercise, at } \\
\text { the level of the right patellar tendon, received a peri-patellar } \\
\text { infiltration of } 300 \mu \mathrm{L} \text { of physiological saline solution } \\
\text { (Fresenius Kabi) }\end{array}$ & $\begin{array}{l}\text { UNTRAINED GROUP (6 } \\
\text { rats)-euthanized without training }\end{array}$ & $\begin{array}{l}\text { TENDON ASSESSMENTS-modified semi-quantitative } \\
\text { Movin grading scale (variables included: fiber structure, } \\
\text { fiber arrangement, rounding of the nuclei, regional } \\
\text { variation of cellularity, increased vascularity, collagen } \\
\text { stainability, hyalinization), Tear density. } \\
\text { ENTHESIS ASSESSSMENTS-semi-quantitative score } \\
\text { (variables included: patellar enthesis structure; cell } \\
\text { morphology in calcified cartilage; cell morphology in } \\
\text { non-calcified cartilage; chondrocyte cluster formation in } \\
\text { calcified cartilage; chondrocyte cluster formation in } \\
\text { non-calcified cartilage; tidemark integrity between calcified } \\
\text { and non-calcified cartilage; matrix staining; } \\
\text { vascularization). }\end{array}$ \\
\hline
\end{tabular}


Table 2. Eight papers about clinical studies were selected from literature search.

\begin{tabular}{|c|c|c|c|c|c|c|c|c|}
\hline \multicolumn{9}{|c|}{ Clinical Studies } \\
\hline Article & $\begin{array}{c}\text { Sample } \\
\text { Description }\end{array}$ & Pathology & Injection Technique & Experimental Group & Control Group & Follow-Up & Outcome & Adverse Events \\
\hline $\begin{array}{l}\text { Meloni et al., } \\
2007\end{array}$ & $\begin{array}{c}\text { Age }=31-71 \\
N=56\end{array}$ & $\begin{array}{c}\text { Supraspinatus } \\
\text { tendinosis } \\
\text { (unresponsive to } \\
\text { physical and medical } \\
\text { therapy) }\end{array}$ & $\begin{array}{l}5 \text { periarticularinjections } \\
\text { (1/week) under } \\
\text { ultrasoundguide }\end{array}$ & $\begin{array}{c}20 \mathrm{mg} \text { Sodium } \\
\text { hyaluronate } \\
(\mathrm{MW}=500-730 \mathrm{KDa}) \\
\text { together with } 2 \mathrm{~mL} \text { of } \\
1 \% \text { lidocaine and } 2 \mathrm{~mL} \\
\text { of } 0.9 \% \text { sodium } \\
\text { chloride solution } \\
\end{array}$ & $\begin{array}{c}4 \mathrm{~mL} \text { of } 0.9 \% \text { sodium } \\
\text { chloride solution, } \\
\text { together with } 2 \mathrm{~mL} \text { of } \\
1 \% \text { lidocaine }\end{array}$ & $\begin{array}{c}\text { ultrasound exam } \\
\text { controls at } 3,6 \text { and } \\
12 \text { months from the last } \\
\text { injection }\end{array}$ & $\begin{array}{c}\text { Shoulder Range of motion } \\
\text { (goniometer), Pain (VAS), degree of } \\
\text { discomfort }\end{array}$ & $\begin{array}{c}\text { There were no complications } \\
\text { such as infections and no } \\
\text { aggravations of symptoms } \\
\text { compared with the } \\
\text { pre-treatment state in either } \\
\text { group }\end{array}$ \\
\hline $\begin{array}{l}\text { Blaine et al., } \\
2008\end{array}$ & $\begin{array}{c}\text { Age }=50-79 \\
\mathrm{~N}=79\end{array}$ & $\begin{array}{l}\text { Shoulder pain due to } \\
\text { glenohumeral joint } \\
\text { osteoarthritis, rotator } \\
\text { cuff tear (partial or } \\
\text { complete), and/or } \\
\text { adhesive capsulitis for } \\
\text { at least } 6 \text { months but } \\
\text { less than } 5 \text { years' } \\
\text { refractory to standard } \\
\text { treatments (physical } \\
\text { therapy, corticosteroid } \\
\text { injections and the } \\
\text { administration of oral } \\
\text { pain medications) }\end{array}$ & $\begin{array}{l}5 \text { intra-articular } \\
\text { glenohumeralinjections } \\
\text { (1/week })\end{array}$ & $\begin{array}{c}\text { 5 INJECTION } \\
\text { HYALURONATE } \\
\text { GROUP-2 mL sodium } \\
\text { hyaluronate (molecular } \\
\text { weight, 500-730 kDa) } \\
\text { 3 INJECTION } \\
\text { HYALURONATE } \\
\text { GROUP-three } \\
\text { injections of sodium } \\
\text { hyaluronate (500-730 } \\
\text { KDa) followed by two } \\
\text { injections of } \\
\text { phosphate-buffered } \\
\text { saline solution }\end{array}$ & $\begin{array}{l}\text { CONTROL GROUP-2 } \\
\text { mL injections of } \\
\text { phosphate-buffered } \\
\text { saline solution }\end{array}$ & $\begin{array}{c}7,9,13,17 \text {, and } \\
26 \text { weeks after the } \\
\text { initiation of therapy }\end{array}$ & $\begin{array}{l}\text { Pain (VAS), maintenance of visual } \\
\text { analogic scale pain relief, night } \\
\text { pain improvement, patient global } \\
\text { assessments, shoulder range of } \\
\text { motion, general health } \\
\text { questionnaire (short-form health } \\
\text { survey-12) }\end{array}$ & $\begin{array}{l}\text { All treatments were well } \\
\text { tolerated. The most frequently } \\
\text { reported adverse event } \\
\text { considered to be related to } \\
\text { study treatment was } \\
\text { injection-site pain. }\end{array}$ \\
\hline $\begin{array}{l}\text { Frizziero et al., } \\
\qquad 2017\end{array}$ & $\begin{array}{c}\text { Age }=18-85 \\
\mathrm{~N}=34\end{array}$ & $\begin{array}{c}\text { Painful } \\
\text { non-calcific rotator cuff } \\
\text { tendinopathies } \\
\text { confirmed by } \\
\text { Instrumental diagnosis } \\
\text { (US or MRI) }\end{array}$ & $\begin{array}{l}3 \text { sub-acromial space } \\
\text { injections ( } 1 / \text { week }) \\
\text { under ultrasound } \\
\text { guidance }\end{array}$ & $\begin{array}{l}2 \mathrm{~mL} \text { Hyaluronic acid } \\
(\mathrm{MW}=500-730 \mathrm{kDa})\end{array}$ & $\begin{array}{l}4 \text { weeks }(1 / \text { week) low } \\
\text { energy extracorporeal } \\
\text { shockwave therapy } \\
\left.\text { (MODULITH }{ }^{\oplus}\right) \text {; each } \\
\text { session consisted of } \\
1600 \text { shots at a } \\
\text { frequency of } 4 \mathrm{~Hz} \text {. The } \\
\text { applied maximum } \\
\text { energy }\left(0.15 \mathrm{~mJ} / \mathrm{mm}^{2}\right) \\
\text { was adjusted on the } \\
\text { basis of the patient's } \\
\text { tolerance, Mean session } \\
\text { duration: } 10 \text { min. }\end{array}$ & $\begin{array}{l}\text { Parameters were } \\
\text { evaluated at baseline } \\
\text { (V0), at the end of the } \\
\text { treatment (V1) and } \\
\text { after } 3 \text { months of } \\
\text { follow-up (V2) }\end{array}$ & $\begin{array}{l}\text { Disabilities of the arm (DASH score } \\
\text { and Constant-Murley scales) }\end{array}$ & $\begin{array}{l}\text { No serious adverse events } \\
\text { were recorded }\end{array}$ \\
\hline $\begin{array}{l}\text { Fogli et al., } \\
2017\end{array}$ & $\begin{array}{c}\text { Age }=33-59 \\
\mathrm{~N}=62\end{array}$ & $\begin{array}{l}\text { lateral elbow (26), } \\
\text { Achilles (34) or patellar } \\
\text { (11) tendinopathies }\end{array}$ & $\begin{array}{c}3 \text { peritendinous } \\
\text { injections (1/week) } \\
\text { under ecographic guide }\end{array}$ & $\begin{array}{l}2 \mathrm{~mL} \text { Hyaluronic acid } \\
(\mathrm{MW}=500-730 \mathrm{kDa})\end{array}$ & & $\begin{array}{l}7,14, \text { and } 56 \text { days after } \\
\text { first treatment }\end{array}$ & $\begin{array}{l}\text { Pain (VAS), ultrasound assessment } \\
\text { (changes in tendon thickness and } \\
\text { neovascularization) }\end{array}$ & $\begin{array}{l}\text { No serious adverse events } \\
\text { were recorded }\end{array}$ \\
\hline $\begin{array}{l}\text { Frizziero et al., } \\
2019\end{array}$ & $\begin{aligned} \text { Age } & =18-65 \\
\mathrm{~N} & =35\end{aligned}$ & $\begin{array}{c}\text { Achilles (26) and } \\
\text { patellar (9) mid-portion } \\
\text { tendinopathies for } \geq 6 \\
\text { weeks duration and } \\
\text { confirmed by } \\
\text { ultrasound evaluation }\end{array}$ & $\begin{array}{c}3 \text { peritendinous } \\
\text { injection }(1 / \text { week }) \\
\text { between paratenon and } \\
\text { tendon under } \\
\text { Ecographic guide }\end{array}$ & $\begin{array}{c}20 \mathrm{mg} / 2 \mathrm{~mL} \\
\text { Hyaluronic acid } \\
\text { (HyaloTend }{ }^{\circledR}, \text { Fidia, } \\
\mathrm{MW}=500-730 \mathrm{KDa})\end{array}$ & & $\begin{array}{l}14,45 \text { and } 90 \text { days after } \\
\text { the procedure }\end{array}$ & $\begin{array}{l}\text { VISA-A and VISA-P at } 90 \text { days of } \\
\text { follow-up, pain (NRS-11), US } \\
\text { parameters (tendon appearance } \\
\text { and neovascularization), Patient } \\
\text { Global Assessment (PGA), Clinical } \\
\text { Observer Global Assessment } \\
\text { (COGA), rescue medication } \\
\text { consumption (paracetamol) and } \\
\text { Health-related Quality of Life } \\
\text { (EuroQoL EQ-5D-5L questionnaire) }\end{array}$ & $\begin{array}{l}\text { The treatment was well } \\
\text { tolerated with only one } \\
\text { adverse events in Achilles } \\
\text { tendinopathy group, probably } \\
\text { related to the injection } \\
\text { procedure }\end{array}$ \\
\hline
\end{tabular}


Table 2. Cont.

\begin{tabular}{|c|c|c|c|c|c|c|c|c|}
\hline \multicolumn{9}{|c|}{ Clinical Studies } \\
\hline Article & $\begin{array}{c}\text { Sample } \\
\text { Description }\end{array}$ & Pathology & Injection Technique & Experimental Group & Control Group & Follow-Up & Outcome & Adverse Events \\
\hline $\begin{array}{l}\text { Kanchanathepsak } \\
\text { et al., } 2020\end{array}$ & $\begin{aligned} \text { Age } & =43-69 \\
\mathrm{~N} & =66\end{aligned}$ & Trigger digits & $\begin{array}{l}1 \text { peritendinous } \\
\text { injection under } \\
\text { ecographic guide }\end{array}$ & $\begin{array}{c}1 \mathrm{~mL} \text { hyaluronic acid } \\
(500-730 \mathrm{kD} \\
20 \mathrm{mg} / 2 \mathrm{~mL})\end{array}$ & $\begin{array}{l}1 \mathrm{~mL} \text { of } 10 \mathrm{mg} / \mathrm{mL} \text { of } \\
\text { triamcinolone acetate }\end{array}$ & $1,3,6$ months & $\begin{array}{l}\text { Residual symptoms (Quinell } \\
\text { grading), Pain (VAS), disabilities of } \\
\text { the Arm (DASH score) }\end{array}$ & $\begin{array}{l}\text { There was no major } \\
\text { complication found in the } \\
\text { study. Three patients } \\
\text { complained about local } \\
\text { discomfort at } 1 \text { week after } \\
\text { injection without any sign of } \\
\text { local inflammation. }\end{array}$ \\
\hline $\begin{array}{l}\text { Mohebbi et al., } \\
2021\end{array}$ & $\begin{aligned} \text { Age } & =16-70 \\
\mathrm{~N} & =56\end{aligned}$ & $\begin{array}{c}\text { Rotator cuff } \\
\text { tendinopathy (based on } \\
\text { history, physical } \\
\text { examination, and } \\
\text { magnetic resonance } \\
\text { imaging) with } \\
\text { persistent shoulder } \\
\text { pain for more than } \\
6 \text { weeks and less than } \\
36 \text { months }\end{array}$ & $\begin{array}{l}\text { Single periarticular } \\
\text { injection under } \\
\text { ultrasound guidance }\end{array}$ & $\begin{array}{c}20 \mathrm{mg}(2 \mathrm{~mL}) \text { LMW-HA } \\
1 \%(500-730 \mathrm{kDa})\end{array}$ & $\begin{array}{c}20 \mathrm{mg}(2 \mathrm{~mL}) \\
\text { HMW-HA 1\% } \\
\text { (>2000 kDa, Synogel, } \\
\text { NikanTebKimia } \\
\text { Pharmaceutical). }\end{array}$ & $\begin{array}{l}\text { baseline, } 1,4 \text { weeks, } \\
\text { and } 3 \text { months after the } \\
\text { interventions }\end{array}$ & $\begin{array}{l}\text { Pain (VAS), shoulder range of } \\
\text { motion (goniometer), quality of life } \\
\text { (WHOQOL-Bref) }\end{array}$ & $\begin{array}{l}\text { No serious adverse events } \\
\text { were recorded. Nine patients } \\
\text { in the HMW-HA group and } \\
3 \text { participants in the LMW-HA } \\
\text { group showed signs of } \\
\text { inflammation at the site of } \\
\text { injection. Overall, the } \\
\text { LMW-HA group showed more } \\
\text { tolerance to injection pain }\end{array}$ \\
\hline $\begin{array}{l}\text { Rezasoltani } \\
\text { et al., } 2021\end{array}$ & $\begin{aligned} \text { Age } & =20-65 \\
\mathrm{~N} & =51\end{aligned}$ & $\begin{array}{c}\text { Supraspinatus } \\
\text { tendinopathy (based on } \\
\text { history, physical } \\
\text { examination, and } \\
\text { magnetic resonance } \\
\text { imaging) with } \\
\text { persistent shoulder } \\
\text { pain for more than } 6 \\
\text { weeks and less than } 3 \\
\text { months }\end{array}$ & $\begin{array}{l}\text { Single subacromial } \\
\text { injection under } \\
\text { ultrasound guidance }\end{array}$ & $\begin{array}{l}20 \mathrm{mg}(2 \mathrm{~mL}) \text { LMW-HA } \\
1 \%(500-730 \mathrm{kDa}) .\end{array}$ & $\begin{array}{l}\text { Physiotherapy group: } \\
36 \text { sessions, 3/week. }\end{array}$ & $\begin{array}{l}\text { Baseline, } 1,4 \text {, and } \\
12 \text { weeks } \\
\text { postintervention. }\end{array}$ & $\begin{array}{l}\text { Pain (VAS), shoulder range of } \\
\text { motion (goniometer), disabilities of } \\
\text { the Arm (DASH score), quality of } \\
\text { life (WHOQOL-Bref) }\end{array}$ & $\begin{array}{l}\text { No important adverse events } \\
\text { occurred in the two groups }\end{array}$ \\
\hline
\end{tabular}




\subsection{Pre-Clinical Studies}

Salamanna et al. investigated the effects of repeated peri-patellar injections of LMWHA (500-730 KDa) in sudden-detraining rat model tendinopathy, founding that HA allow the maintenance of tenocyte anabolic activity and proliferation in comparison to saline or no intervention [45].

Furthermore, in a second study Frizziero et al. demonstrated that repeated peripatellar injections of LMW-HA may maintain the structural and functional properties of patellar tendon and enthesis in sudden detrained rats [46].

\subsection{Clinical Studies}

Meloni et al. found that five US-guided LMW-HA injections were effective compared to placebo in improving pain and function in 56 patients affected by supraspinatus tendinosis until 9 months [47].

Blaine et al. found that LMW-HA (500 to $730 \mathrm{kDa}$ ) injection is effective in the short term and well tolerated for the treatment of osteoarthritis and persistent shoulder pain (including rotator cuff tear) that is refractory to other standard non operative interventions [48].

Frizziero et al. observed that LMW-HA (500 to $730 \mathrm{kDa}$ ) and low-energy ESWT were both effective and safe in patients suffering from non-calcific rotator cuff tendinopathy until a 3-month follow-up. However, LMW-HA provide prompt clinical improvement compared to ESWT [28].

Fogli et al. have shown that three US-guided LMW-HA paratendinous injections induce significant progressive improvement in pain and function and US parameters (tendon thickness and neovascularization) in patients with Achilles or patellar tendinopathies [49].

Similar good results in terms of pain reduction and improvement of function in Achilles and patellar tendinopathy have also been observed by Frizziero et al. following US-guided paratendinous injection treatment [50].

Kanchanathepsak et al. compared the efficacy of US-guided injection of LMW-HA (500-730 KDa) and corticosteroids (triamcinolone acetate) in the treatment of trigger finger. The authors noted that both LMW-HA and corticosteroids provide a comparable therapeutic effect in the medium term. However, it is necessary to consider that corticosteroids have a cytotoxic effect on tendons [51].

Recently, Mohebbi et al. evaluated the clinical effects of HMW-HA (>2000 kDa) versus LMW-HA (500-730 KDa) single US-guided periarticular injection in the management of rotator cuff tendinopathy with persistent shoulder pain for more than 6 weeks. The pain, induration, and inflammation at the site of injection are less prominent for LMW-HA compared with HMW-HA. Even both preparations were effective in improving pain, joint function, and quality of life that last at least for 3 months, LMW-HA is less expensive and resulted more tolerable to the patient. LMW-HA seems also more effective than physiotherapy in alleviating pain and improving shoulder ROM and quality of life. Furthermore, patient compliance was higher with LMW-HA injection in relation to lower perceived pain [52].

Rezasoltani et al. compared the effects of LMW-HA injection with physiotherapy in patients with supraspinatus tendinopathy and concluded that injection therapy showed greater efficacy at a 3-month follow-up. In particular, hyaluronic acid is more successful in relieving pain [53].

\section{Discussion}

In past years, intra-articular injections of hyaluronic acid were a well-known and widely used option in the conservative treatment of osteoarthritis with positive results. On the other hand, the role of HA in tendinopathies was underestimated. Although further studies are needed to demonstrate the clinical efficacy and safety of hyaluronic acid in the management of tendinopathies, several studies demonstrated positive effects on tendinopathies with low molecular weight hyaluronic acid injections. 
The more frequent performance of ultrasound evaluation and the possibility of positioning the therapeutic substance with extreme precision in the affected site have allowed for better results in the clinical field.

The results observed in in-vitro studies have showed protective effects against the oxidative stress-related cytotoxicity in the tendon derived cells treated with the three lower molecular weight HAs $[43,44]$.

Osti et al. identified a protective effect of the tendon by hyaluronic acid, related to the very low expression for the production of collagen type III [43].

The encouraging effects of hyaluronic acid in conditions of tendon suffering have also been confirmed in pre-clinical studies [45,46]. Salamanna et al. [45] and Frizziero et al. [46] investigated the effects of repeated peri-patellar injections of low molecular weight HA (500-730 KDa) on tenocytes morphology, viability, proliferation, and metabolic activity and both the authors concluded that HA injections at the end of the I, II, III, and IV weeks in detrained tendinopathies rat model seems to help tenocytes to maintain their synthetic and metabolic activities, the structural and functional properties of the patellar tendon in ensuring safety.

Following the results just described where LMW-HA has shown the potential to determine amelioration of tendon behavior via change in tenocyte viability and proliferation and collagen composition were promoted clinical studies on human different tendon's site (rotator cuff tendons, patellar tendon, Achilles tendon, etc.) with encouraging conclusions [47-53].

In fact, the results obtained by Meloni et al. [47] in rotator cuff pathology shows better results with hyaluronic acid than placebo, while Frizziero et al. [28] demonstrated faster efficacy of injections with low molecular weight hyaluronic acid compared to shock waves.

Thus, it could be speculated that LMW-HA should contribute to the restoration of the essential viscoelastic properties of tendon, leading to function improvement without side effects.

Mohebbi et al. [52] observed in a recent comparative study between ultrasoundguided injections with low molecular weight (500-730 KDa) and high molecular weight (>2000 KDa) that, with the same effectiveness, low molecular weight was more tolerated by patients.

Rezasoltani et al. [53] and Blaine et al. [48] confirmed the efficacy of low molecular weight hyaluronic acid (500-730 KDa) injection in pain relief and function amelioration.

Similar positive results on pain and functional recovery have been observed in the clinical experiences of Frizziero et al. [50] and Fogli et al. [49] in the Achilles tendon, patellar tendon, and epicondylitis.

Pathological conditions such as tenosynovitis also benefited from injection treatment with low molecular weight hyaluronic acid (500-730 KDa) in comparison to triamcinolone acetonide. Despite the corticosteroid produced more rapid remission of the symptoms, hyaluronic acid was also shown to be safer and produced a longer lasting effect [51].

All the studies have found that clinical effectiveness should be reached already at 1 month after the LMW-HA injections; this finding should be crucial in athletes that need safe and rapid return to sport participation.

Furthermore, it appears that LMW-HA injection was highly tolerated by patients, with only rare local, self-limiting side-effects. In specific, LMW-HA presented better tolerability and minor costs in comparison to HMW-HA formulations [52].

\section{Conclusions}

Tendinopathies are a group of pathologies that afflict the tendons and nowadays there are many current treatment options, but none has shown particular superiority. Among these therapeutic proposals and following favorable results observed with in vitro, preclinical, and clinical studies, the use of low molecular weight hyaluronic acid by injection should be encouraged compared to high-weight hyaluronic acid. The rapid action and the high safety profile make this treatment particularly suitable for athletes. To achieve extreme 
accuracy of positioning of hyaluronic acid, the use of ultrasound guidance is strongly recommended. Even the lower cost compared to hyaluronic acids with higher molecular weight can represent an additional incentive to its use.

\section{Limitations of the Review}

Despite the limitations of our study represented by the low number of papers in the literature and the small number of patients treated, the results obtained encourage the use of low molecular weight hyaluronic acid in tendinopathies. For these reasons, further studies are needed to produce more evidence of efficacy of low molecular weight hyaluronic acid in tendinopathies.

Author Contributions: Conceptualization, A.F.; methodology, A.F. and F.V.; validation, A.F., D.B. and C.C.; formal analysis, A.F.; investigation, A.F.; writing-original draft preparation, A.F. and D.B.; writing-review and editing, A.F. and F.V.; supervision, C.C. All authors have read and agreed to the published version of the manuscript.

Funding: This research received no external funding.

Institutional Review Board Statement: Not applicable.

Informed Consent Statement: Not applicable.

Data Availability Statement: The study does not report any data.

Conflicts of Interest: The authors declare no conflict of interest.

\section{References}

1. Challoumas, D.; Biddle, M.; Millar, N.L. Recent advances in tendinopathy. Fac. Rev. 2020, 9, 16. [CrossRef]

2. Merolla, G.; Singh, S.; Paladini, P.; Porcellini, G. Calcific tendinitis of the rotator cuff: State of the art in diagnosis and treatment. J. Orthop. Traumatol. 2016, 17, 7-14. [CrossRef] [PubMed]

3. Sarmento, M. Long head of biceps: From anatomy to treatment. Acta Reum. Port. 2014, 40, $26-33$.

4. Patrick, N.C.; Hammert, W.C. Hand and Wrist Tendinopathies. Clin. Sports Med. 2020, 39, 247-258. [CrossRef] [PubMed]

5. Sirico, F.; Palermi, S.; Massa, B.; Corrado, B. Tendinopathies of the hip and pelvis in athletes: A narrative review. J. Hum. Sports Exerc. 2020, 15, S748-S762. [CrossRef]

6. Tarantino, D.; Palermi, S.; Sirico, F.; Balato, G.; D'Addona, A.; Corrado, B. Achilles tendon pathologies: How to choose the best treatment. J. Hum. Sport Exerc. 2020, 15, S1300-S1321.

7. Simpson, M.R.; Howard, T.M. Tendinopathies of the foot and ankle. Am. Fam. Physician 2009, 80, 1107-1114. [PubMed]

8. Sharma, P.; Maffulli, N. Basic biology of tendon injury and healing. Surgeon 2005, 3, 309-316. [CrossRef]

9. Waldecker, U.; Hofmann, G.; Drewitz, S. Epidemiologic investigation of 1394 feet: Coincidence of hindfoot malalignment and Achilles tendon disorders. Foot Ankle Surg. 2012, 18, 119-123. [CrossRef]

10. Riley, G.P.; Curry, V.; DeGroot, J.; van El, B.; Verzijl, N.; Hazleman, B.L.; Bank, R.A. Matrix metalloproteinase activities and their relationship with collagen remodelling in tendon pathology. Matrix Biol. 2002, 21, 185-195. [CrossRef]

11. Franceschi, F.; Papalia, R.; Paciotti, M.; Franceschetti, E.; Di Martino, A.; Maffulli, N.; Denaro, V. Obesity as a Risk Factor for Tendinopathy: A Systematic Review. Int. J. Endocrinol. 2014, 2014, 670262. [CrossRef]

12. Longo, U.G.; Ronga, M.; Maffulli, N. Achilles tendinopathy. Sports Med. Arthrosc. Rev. 2009, 17, 112-126. [CrossRef] [PubMed]

13. Oliva, F.; Piccirilli, E.; Berardi, A.C.; Frizziero, A.; Tarantino, U.; Maffulli, N. Hormones and tendinopathies: The current evidence. Br. Med Bull. 2016, 117, 39-58. [CrossRef] [PubMed]

14. Frizziero, A.; Vittadini, F.; Gasparre, G.; Masiero, S. Impact of oestrogen deficiency and aging on tendon: Concise review. Muscle Ligaments Tendons J. 2019, 4, 324-328. [CrossRef]

15. Maffulli, N.; Reaper, J.A.; Waterston, S.W.; Ahya, R. ABO Blood Groups and Achilles Tendon Rupture in the Grampian Region of Scotland. Clin. J. Sport Med. 2000, 10, 269-271. [CrossRef]

16. Maffulli, N.; Sharma, P.; Luscombe, K.L. Achilles tendinopathy: Aetiology and management. J. R. Soc. Med. 2004, 97, 472-476. [CrossRef]

17. Frizziero, A.; Fini, M.; Salamanna, F.; Veicsteinas, A.; Maffulli, N.; Marini, M. Effect of training and sudden detraining on the patellar tendon and its enthesis in rats. BMC Musculoskelet. Disord. 2011, 12, 20. [CrossRef]

18. van der Linden, P.D.; Sturkenboom, M.C.J.M.; Herings, R.M.C.; Leufkens, H.M.G.; Rowlands, S.; Stricker, B.H.C. Increased risk of achilles tendon rupture with quinolone antibacterial use, especially in elderly patients taking oral corticosteroids. Arch. Intern. Med. 2003, 163, 1801-1807. [CrossRef] [PubMed]

19. Bisaccia, D.R.; Aicale, R.; Tarantino, D.; Peretti, G.; Maffulli, N. Biological and chemical changes in fluoroquinolone-associated tendinopathies: A systematic review. Br. Med Bull. 2019, 130, 39-49. [CrossRef] [PubMed] 
20. Di Meglio, F.; Sacco, A.M.; Belviso, I.; Romano, V.; Sirico, F.; Loiacono, C.; Palermi, S.; Pempinello, C.; Montagnani, S.; Nurzynska, D.; et al. Influence of Supplements and Drugs used for the Treatment of Musculoskeletal Disorders on Adult Human TendonDerived Stem Cells. Muscle Ligaments Tendons J. 2020, 10, 376. [CrossRef]

21. Romero, E.A.S.; Pollet, J.; Pérez, S.M.; Pérez, J.L.A.; Fernández, A.C.M.; Pedersini, P.; Carballar, C.B.; Villafañe, J.H. Lower Limb Tendinopathy Tissue Changes Assessed through Ultrasound: A Narrative Review. Medicina 2020, 56, 378. [CrossRef] [PubMed]

22. Ker, R.F. Dynamic tensile properties of the plantaris tendon of sheep (Ovisaries). J. Exp. Biol. 1981, 93, 283-302. [CrossRef]

23. Cook, J.L.; Purdam, C.R. Is tendon pathology a continuum? A pathology model to explain the clinical presentation of load-induced tendinopathy. Br. J. Sports Med. 2009, 43, 409-416. [CrossRef] [PubMed]

24. Frizziero, A.; Bonsangue, V.; Trevisan, M.; Ames, P.R.J.; Masiero, S. Foot tendinopathies in rheumatic diseases: Etiopathogenesis, clinical manifestations and therapeutic options. Clin. Rheumatol. 2012, 32, 547-555. [CrossRef] [PubMed]

25. Aicale, R.; Bisaccia, R.D.; Oliviero, A.; Oliva, F.; Maffulli, N. Current pharmacological approaches to the treatment of tendinopathy. Expert Opin. Pharmacother. 2020, 21, 1467-1477. [CrossRef]

26. Frizziero, A.; Vittadini, F.; Fusco, A.; Giombini, A.; Masiero, S. Efficacy of eccentric exercise for lower limb tendinopathies in athletes. J. Sports Med. Phys. Fit. 2015, 56, 1352-1358.

27. Frizziero, A.; Trainito, S.; Oliva, F.; Aldini, N.N.; Masiero, S.; Maffulli, N. The role of eccentric exercise in sport injuries rehabilitation. Br. Med Bull. 2014, 110, 47-75. [CrossRef]

28. Frizziero, A.; Vittadini, F.; Barazzuol, M.; Gasparre, G.; Finotti, P.; Meneghini, A.; Maffulli, N.; Masiero, S. Extracorporeal shockwaves therapy versus hyaluronic acid injection for the treatment of painful non-calcific rotator cuff tendinopathies: Preliminary results. J. Sports Med. Phys. Fit. 2017, 57, 1162-1168. [CrossRef] [PubMed]

29. Galletti, S.; Oliva, F.; Masiero, S.; Frizziero, A.; Galletti, R.; Schiavone, C.; Salini, V.; Abate, M. Sonoelastography in the diagnosis of tendinopathies: An added value. Muscle Ligaments Tendons J. 2015, 5, 325-330. [CrossRef]

30. Frizziero, A.; Vittadini, F.; Bigliardi, D.; Costantino, C. The Role of Hyaluronic Acid Injection for the Treatment of Tendinopathy. Muscle Ligaments Tendons J. 2020, 10, 548. [CrossRef]

31. Collins, T.; Alexander, D.; Barkatali, B. Platelet-rich plasma: A narrative review. EFORT Open Rev. 2021, 6, 225-235. [CrossRef]

32. Kakkos, G.A.; Klontzas, M.E.; Koltsakis, E.; Karantanas, A.H. US-guided high-volume injection for Achilles tendinopathy. J. Ultrason. 2021, 21, e127-e133. [CrossRef]

33. Arias-Vázquez, P.I.; Tovilla-Zárate, C.A.; González-Graniel, K.; Burad-Fonz, W.; González-Castro, T.B.; López-Narváez, M.L.; Castillo-Avila, R.G.; Arcila-Novelo, R. Efficacy of hypertonic dextrose infiltrations for pain control in rotator cuff tendinopathy: Systematic review and meta-analysis. Acta Reum. Port. 2021, 46, 156-170.

34. Morath, O.; Beck, M.; Taeymans, J.; Hirschmüller, A. Sclerotherapy and prolotherapy for chronic patellar tendinopathies-A promising therapy with limited available evidence, a systematic review. J. Exp. Orthop. 2020, 7, 1-11. [CrossRef]

35. Von Wehren, L.; Pokorny, K.; Blanke, F.; Sailer, J.; Majewski, M. Injection with autologous conditioned serum has better clinical results than eccentric training for chronic Achilles tendinopathy. Knee Surg. Sports Traumatol. Arthrosc. 2019, 27, $2744-2753$. [CrossRef]

36. Fernández, A.C.M.; Carballar, C.B.; Villafañe, J.H.; Pérez, M.M.; Pérez, J.L.; Díaz-Meco, R.; Jiménez, D.G.; Romero, E.A.S. A new ultrasound-guided percutaneous electrolysis and exercise treatment in patellar tendinopathy: Three case reports. Front. Biosci. 2021, 26, 1166-1175.

37. Necas, J.; Bartosikova, L.; Brauner, P.; Kolar, J. Hyaluronic acid (hyaluronan): A review. Vet. Med. 2008, 53, 397-411. [CrossRef]

38. Kaux, J.-F.; Samson, A.; Crielaard, J.-M. Hyaluronic acid and tendon lesions. Muscle Ligaments Tendons J. 2015, 5, 264-269. [CrossRef]

39. Altman, R.; Hackel, J.; Niazi, F.; Shaw, P.; Nicholls, M. Efficacy and safety of repeated courses of hyaluronic acid injections for knee osteoarthritis: A systematic review. Semin. Arthritis Rheum. 2018, 48, 168-175. [CrossRef]

40. Frizziero, A.; Maffulli, N.; Masiero, S.; Frizziero, L. Six-months pain relief and functional recovery after intra-articular injections with hyaluronic acid (mw 500-730 KDa) in trapeziometacarpal osteoarthritis. Muscle Ligaments Tendons J. 2019, 4, $256-261$. [CrossRef]

41. Foti, C.; Cisari, C.; Carda, S.; Giordan, N.; Rocco, A.; Frizziero, A.; Della Bella, G. A prospective observational study of the clinical efficacy and safety of intra-articular sodium hyaluronate in synovial joints with osteoarthritis. Eur. J. Phys. Rehabil. Med. 2011, 47, 407-415.

42. Frizziero, A.; Vittadini, F.; Oliva, F.; Abatangelo, G.; Bacciu, S.; Berardi, A. IS Mu. LT Hyaluronic acid injections in musculoskeletal disorders guidelines. Muscles Ligaments Tendons J. 2018, 8, 364-398. [CrossRef]

43. Osti, L.; Berardocco, M.; Di Giacomo, V.; Di Bernardo, G.; Oliva, F.; Berardi, A.C. Hyaluronic acid increases tendon derived cell viability and collagen type I expression in vitro: Comparative study of four different Hyaluronic acid preparations by molecular weight. BMC Musculoskelet. Disord. 2015, 16, 284, Erratum in BMC Musculoskelet Disord. 2015, 16, 334. [CrossRef]

44. Gallorini, M.; Berardi, A.C.; Berardocco, M.; Gissi, C.; Maffulli, N.; Cataldi, A.; Oliva, F. Hyaluronic acid increases tendon derived cell viability and proliferation in vitro: Comparative study of two different hyaluronic acid preparations by molecular weight. Muscle Ligaments Tendons J. 2017, 7, 208-214. [CrossRef]

45. Salamanna, F.; Frizziero, A.; Pagani, S.; Giavaresi, G.; Curzi, D.; Falcieri, E.; Marini, M.; Abruzzo, P.M.; Martini, L.; Fini, M. Metabolic and cytoprotective effects ofin vivoperi-patellar hyaluronic acid injections in cultured tenocytes. Connect. Tissue Res. 2014, 56, 35-43. [CrossRef] [PubMed] 
46. Frizziero, A.; Salamanna, F.; Giavaresi, G.; Ferrari, A.; Martini, L.; Marini, M.; Veicsteinas, A.; Maffulli, N.; Masiero, S.; Fini, M.; et al. Hyaluronic acid injections protect patellar tendon from detraining-associated damage. Histol. Histopathol. 2015, 30, 1079-1088. [CrossRef]

47. Meloni, F.; Milia, F.; Cavazzuti, M.; Doria, C.; Lisai, P.; Profili, S.; Meloni, G. Clinical evaluation of sodium hyaluronate in the treatment of patients with sopraspinatus tendinosis under echographic guide: Experimental study of periarticular injections. Eur. J. Radiol. 2008, 68, 170-173. [CrossRef] [PubMed]

48. Blaine, T.; Moskowitz, R.; Udell, J.; Skyhar, M.; Levin, R.; Friedlander, J.; Daley, M.; Altman, R. Treatment of Persistent Shoulder Pain with Sodium Hyaluronate: A Randomized, Controlled Trial. J. Bone Jt. Surg.-Am. Vol. 2008, 90, 970-979. [CrossRef]

49. Fogli, M.; Giordan, N.; Mazzoni, G. Efficacy and safety of hyaluronic acid (500-730 kDa) Ultrasound-guided injections on painful tendinopathies: A prospective, open label, clinical study. Muscles Ligaments Tendons J. 2017, 7, 388-395. [CrossRef]

50. Frizziero, A.; Oliva, F.; Vittadini, F.; Vetrano, M.; Bernetti, A.; Giordan, N.; Vulpiani, M.C.; Santilli, V.; Masiero, S.; Maffulli, N. Efficacy of ultrasound-guided hyaluronic acid injections in achilles and patellar tendinopathies: A prospective multicentric clinical trial. Muscles Ligaments Tendons J. 2019, 9, 305-313. [CrossRef]

51. Kanchanathepsak, T.; Pichyangkul, P.; Suppaphol, S.; Watcharananan, I.; Tuntiyatorn, P.; Tawonsawatruk, T. Efficacy Comparison of Hyaluronic Acid and Corticosteroid Injection in Treatment of Trigger Digits: A Randomized Controlled Trial. J. Hand Surg. 2020, 25, 76-81. [CrossRef] [PubMed]

52. Mohebbi, R.; Rezasoltani, Z.; Mir, M.; Mohebbi, M.; Vatandoost, S.; Esmaily, H. High-Versus Low-Molecular-Weight Hyaluronic Acid for the Treatment of Rotator Cuff Tendinopathy: A Triple-Blind Randomized Comparative Trial. Ann. Pharmacother. 2021, 55, 1203-1214. [CrossRef] [PubMed]

53. Rezasoltani, Z.; Esmaily, H.; Dadarkhah, A.; Rousta, M.; Mohebbi, R.; Vashaei, F. Low Molecular-weight Hyaluronic Acid Versus Physiotherapy for the Treatment of Supraspinatus Tendinopathy: A Randomized Comparative Clinical Trial. J. Am. Acad. Orthop. Surg. 2021, 29, e979-e992. [CrossRef] 